\title{
KIT NP_000213.1:p.D820Y
}

National Cancer Institute

\section{Source}

National Cancer Institute. KIT NP 000213.1:p.D820Y. NCI Thesaurus. Code C155702.

A change in the amino acid residue at position 820 in the mast/stem cell growth factor receptor Kit protein where aspartic acid has been replaced by tyrosine. 